\title{
Correlation between physical fitness and primary dysmenorrhea in teenagers students at a state junior high school in Gianyar
}

\author{
Ni Putu Ana Novita ${ }^{1}$, I Made Sarmadi ${ }^{1}$, Made Dharmesti Wijaya ${ }^{{ }^{*}}$ \\ ${ }^{1}$ Faculty of Medicine and Health Sciences, Warmadewa University \\ *dharmestiwijaya@gmail.com
}

\begin{abstract}
Primary dysmenorrhea or menstrual cramps without pelvic pathology is a common health problem among women in reproductive age. Primary dysmenorrhea usually occurs within 6-24 months post-menarche and at the age of around 20 years old. Physical activity has been claimed to have beneficial effects on primary dysmenorrhea, yet high-quality evidence is lacking. This study was aimed to determine the prevalence of dysmenorrhea in teenagers students and its correlation with physical fitness. A crosssectional survey was conducted on 71 female students at a state junior high school namely SMP Negeri 3 in Gianyar, Bali, Indonesia. Physical fitness was measured using Indonesian Physical Fitness Test (Tes Kesegaran Jasmani Indonesia, TKJI) while dysmenorrhea data were collected by using questionnaires and analysed using Somers'd test. The results show that the physical fitness level of $8.5 \%$ participants were very low, $50.7 \%$ were low, $35.2 \%$ were moderate, and $5.6 \%$ were high. Moreover, $78.9 \%$ of the participants were experiencing dysmenorrhea while $21.1 \%$ of them were not. Statistical analysis indicated that there was a significant correlation between physical fitness and dysmenorrhea $(p<0.005)$. Therefore, we conclude that there is a significant positive correlation between physical fitness and dysmenorrhea.
\end{abstract}

Keywords: teacher ability, curriculum 2013, scientific approach

\section{Introduction}

Monthly cycle or menstruation is a natural and regular occurrence experienced by women between puberty and menopause (12-49 years old) and not pregnant [1]. Menstruation is often followed by dysmenorrhea or painful menstrual cramps that can be classified into primary (spasmodic) and secondary (congestive) dysmenorrhea [2]. Primary dysmenorrhea is a menstrual pain without organic disease while secondary dysmenorrhea is a menstrual pain caused by diseases such as endometriosis, pelvic inflammatory disease, endometrial polyps, adenomyosis, or the use of an intrauterine contraceptive device [3]. The prevalence of dysmenorrhea is high, ranging from 45 to $93 \%$ of women of reproductive age [4].

Primary dysmenorrhea is the most common cause of absenteeism from school or work in adolescent females. This disorder is often linked with the physical fitness of the person. Physical fitness is determined as one's capacity to do daily activities with optimal performance, strength, and endurance with the management of stress, fatigue, and disease, and decreased sedentary behavior [5]. This physical condition can be achieved through physical exercise training, correct nutrition, and proper rest or sleep [6]. 
Some studies on female students indicate the burden of dysmenorrhea on their daily activities. A study on female university students in Ethiopia shows that $88.3 \%$ of the students reported negative impacts of dysmenorrhea on their academic performance including school or class absence and loss of class concentration [7]. Similar study on Hongkong university students indicates that dysmenorrhea decrease the ability to concentrate and affect the physical activity of $75 \%$ and $60 \%$ of the participants respectively [8]. Furthermore, a study in Oman high schools also shows that primary dysmenorrhea is prevalent and negatively impact the academic performance, concentration, and daily activity of the students [9].

The prevalence of dysmenorrhea in Indonesia is $60-70 \%$, in which the percentage of primary dysmenorrhea is about $54 \%$ [10]. A study in a state junior high school in Demak, Central Java, Indonesia shows that only $8.7 \%$ of students who excercise regularly experience dysmenorrhea, compared to $83.7 \%$ of those who do not exercise [11]. Moreover, a study in a senior high school in Denpasar, Bali, Indonesia report the prevalences of dysmenorrhea in students with good physical fitness and not physically fit are $40 \%$ and $88.2 \%$ respectively [12].

Taken together, these data give indications that there is a link between dysmenorrhea prevalence and physical fitness. However, there is still limited study done on the implication of physical fitness and the occurrence of dysmenorrhea among young females, especially in Indonesia. Therefore, this study was aimed to estimate the prevalence of dysmenorrhea in young girl students in Gianyar, Bali, Indonesia, and its correlation with physical fitness of the students. The result of this study is expected to contribute in providing more evidence of the correlation between dysmenorrhea and physical fitness and raising the awareness of the students and society about the importance of exercise and physical fitness in preventing dysmenorrhea.

\section{Method}

\subsection{Study design and setting}

A cross-sectional survey was performed in a state junior high school in Gianyar, Bali, Indonesia, namely SMP Negeri 3 Gianyar, in December 2017. In this school, 9th grade junior high school female students were selected using simple random sampling method. A total of 71 students age 13 to 15 years old were studied

\subsection{Sampling procedure and data analysis}

Data collection for physical fitness was carried out by performing five Indonesian Physical Fitness Test namely 50-meter run test, 800-meter run test, pull-up, sit-up, and vertical jump. The 50-meter run test was used to collect the data for speed while 800-meter run test was considered as test for anaerobic capacity. The time was measured using Seiko stopwatch. Pullup and sit-up tests were done for 60 seconds for each test, and the frequencies were calculated. Moreover, vertical jump test result was determined as the difference between the initial value and the highest jump height value. The interval between each test was three minutes. The total value of the five tests were then classified into very low, low, average, high, and very high according to Indonesian Physical Fitness Test value [13].

Dysmenorrhea data were obtained through direct interviews using questionnaires. The full name, grade, and the age of the participants were collected from students database and crosschecked during interviews. The output of the dysmenorrhea data were "yes" or "no" 
(binomial). The physical fitness and dysmenorrhea data were analysed using Somers'd Correlation Analysis in Statistical Product and Service Solution (SPSS).

\section{Results And Discussion}

\subsection{Respondent characteristics}

A total of 71 respondents were tested using Indonesian Physical Fitness Test and interviewed using questionnaires. The respondents characteristics data including age, age of menarche, duration of menstrual cycle, and cycle length were obtained. The results show that the respondents were aged 13-15 years old with age of menarche at 11-13 years. More than a half of the respondents had menstrual cycle duration of $28-35$ days. In addition, $76.1 \%$ of the respondents had less than 7 days menstrual duration (Table 1).

Table 1. Respondent characteristics

\begin{tabular}{cccc}
\hline \multicolumn{1}{c}{ Parameter } & Frequency & Percentage (\%) \\
\hline Age (years old) & 13 & 1 & \\
14 & 61 & 1.4 \\
15 & 9 & 85.9 \\
Age of menarche (years old) & & 12.7 \\
11 & 9 & \\
12 & 45 & 63.4 \\
13 & 13 & 23.9 \\
Menstrual cycle duration (days) & & \\
$24-27$ & 29 & 40.8 \\
$28-35$ & 42 & 59.2 \\
Menstrual duration (days) & & \\
$<7$ & 54 & 76.1 \\
$>7$ & 17 & 23.9 \\
\hline
\end{tabular}

\subsection{Physical fitness}

Measurement of physical fitness was carried out by conducting Indonesian Physical Fitness Test. The results show that half of the respondents $(50.7 \%)$ had low physical fitness, while only $5.6 \%$ had high physical fitness (Table 2 )..

Table 2. Physical fitness of the respondents

\begin{tabular}{|c|c|c|}
\hline Parameter & Frequency & Percentage (\%) \\
\hline Very low & 6 & 8.5 \\
\hline Low & 36 & 50.7 \\
\hline Average & 25 & 35.2 \\
\hline High & 4 & 5.6 \\
\hline Very high & 0 & 0 \\
\hline
\end{tabular}

\subsection{Dysmenorrhea prevalence}

The prevalence data of dysmenorrhea in SMP Negeri 3 Gianyar female students was collected using questionnaires. The percentage of dysmenorrhea is displayed in Table 3 . Almost $80 \%$ of the respondents experienced dysmenorrhea. 
Table 3. Dysmenorrhea prevalence

\begin{tabular}{lccc}
\hline & Parameter & Frequency & Percentage (\%) \\
\hline Yes & 56 & 78.9 \\
No & 15 & 21.1 \\
\hline
\end{tabular}

\subsection{Correlation between physical fitness and dysmenorrhea}

Half of the respondents have low physical fitness level and most of them experienced dysmenorrhea. Based on Somers'd correlation analysis, there is a significant correlation between physical fitness and dysmenorrhea with $r$ value of 0.250 and $p$ significance value of 0.002 (Table 4).

Table 4. Correlation between physical fitness and dysmenorrhea

\begin{tabular}{lcccc}
\hline Physical Fitness & \multicolumn{2}{c}{ Dysmenorrhea } & & P \\
\cline { 2 - 3 } & Yes & No & & r \\
\hline Very low & 6 & 0 & & \\
Low & 32 & 4 & & 0.250 \\
Average & 16 & 9 & & 0.002 \\
High & 2 & 2 & & \\
Very high & 0 & 0 & & \\
\hline
\end{tabular}

\subsection{Physical fitness}

Physical activity and physical fitness are important for students because there is a positive relationship among physical fitness, physical activity, and academic performance of the students [14]. However, the result of this study shows that $50.7 \%$ and $35.2 \%$ of the respondents have low and average physical fitness respectively while only $5.6 \%$ of them have high physical fitness. Similar study by Agus (2014) reported that $33.52 \%$ and $53.63 \%$ junior high school students respondents in West Java have low and average physical fitness, and only $9.5 \%$ of them have high physical fitness [15].. .

The reason of the low physical fitness of the students could be the limited time for sports or exercises in the school. The students only exercise for 60 minutes a week during physical education class. In addition, most of the students did not take any other sports-related extracurricular activities. The inactive lifestyles such as spending too much time watching television, working on computer, or playing games on the gadget, and also the preference for using vehicle over walking even in a short distance may also play a role in decreasing the physical fitness of the students

One of the strategy to improve physical fitness is by living a healthy and active life. The higher the degree of one's physical fitness, the greater the physical ability and the productivity of their work [15]. Physical fitness can be improved by exercising at least 3-4 times a week with a duration of 30-45 minutes for each exercise [16]. As we get older, the cardiorespiratory endurance will decline. However, this process can be slowed down by exerc

\subsection{Correlation between dysmenorrhea and physical fitness}

This study indicates that there is a significant and positive correlation between dysmenorrhea and physical fitness. It means that the better the physical fitness, the lower the incidence of dysmenorrhea. On the contrary, the lower the physical fitness, the higher the possibility to experience dysmenorrhea. This result is in line with previous studies by Kasrin (2013) and Ramadani (2014) that report significant correlation between sports habit of the 
junior high school students in Bukittingi and Demak with dysmenorrhea prevalence [11, 17]. A study by Andriani and co-workers (2014) also shows a correlation between physical fitness and dysmenorrhea in senior high school female students [12].ising regularly and being physically active from an early age.

Dysmenorrhea is caused by contraction of the myometrium, so that the prostaglandin produced in the endometrium triggers ischemia [18]. The excessive production of prostaglandin F2 $\alpha$ causes uterus contraction and arteriolar vasoconstriction, characterized by pain in the abdomen that radiates to the waist and thigh, and sometimes accompanied by nausea and vomiting, diarrhea, headaches, and emotional instability [12].

The physical fitness obtained through regular exercises induces cardiorespiratory endurance, including heart, lungs, and blood vessels. The increase of oxygen supply to the vasoconstricted blood vessels will decrease the pain caused by uterus contractions. In addition, increasing physical fitness through exercise also help to reduce pain response by supressing prostaglandin production. Exercise generates endorphin hormones, a natural pain relievers that are released into the blood circulation and causes better blood flow around the uterus so that the pain during menstrustion is reduced [12].

\section{Conclusions}

To sum up, we have done a cross-sectional study to determine whether there is a correlation between physical fitness of teenagers students and the occurence of dysmenorrhea. We found that most of the students have average to low physical fitness and $78.9 \%$ of them experienced dysmenorrhea. Based on Somers'd statistical analysis, we conclude that there is a significant positive correlation between physical fitness and dysmenorrhea. .

\section{References}

[1] Novia, I. and N. Puspitasari, Faktor Risiko yang Mempengaruhi Kejadian Dismenore Primer. The Indonesian Journal of Public Health, 2008. 4(3): p. 96-103.

[2] Dawood, M.Y., Dysmenorrhea. J Reprod Med, 1985. 30(3): p. 154-67.

[3] Proctor, M. and C. Farquhar, Diagnosis and management of dysmenorrhoea. BMJ (Clinical research ed.), 2006. 332(7550): p. 1134-1138.

[4] Bernardi, M., et al., Dysmenorrhea and related disorders. F1000Research, 2017. 6: p. 1645-1645.

[5] Campbell N., De Jesus S., Prapavessis H. (2013) Physical Fitness. In: Gellman M.D., Turner J.R. (eds) Encyclopedia of Behavioral Medicine. Springer, New York, NY

[6] Indonesiani S H. (2016) 'Cara-Cara Pengukuran Kesegaran Jasmani', kuliah tentang kesegaran jasmani, pp. 1-2.

[7] Hailemeskel, S., A. Demissie, and N. Assefa, Primary dysmenorrhea magnitude, associated risk factors, and its effect on academic performance: evidence from female university students in Ethiopia. International journal of women's health, 2016. 8: p. 489-496.

[8] Chia, C.F., et al., Dysmenorrhoea among Hong Kong university students: prevalence, impact, and management. Hong Kong Med J, 2013. 19(3): p. 222-8.

[9] Al-Kindi, R. and A. Al-Bulushi, Prevalence and Impact of Dysmenorrhoea among Omani High School Students. Sultan Qaboos University medical journal, 2011. 11(4): p. 485-491.

[10] Fajaryati N. 2012. Hubungan kebiasaan olahraga dengan dismenore primer remaja putri di SMP N 2 Mirit Kebumen. Jurnal Komunikasi Kesehatan (Edisi 4), 3. 
[11] Ramadani A N. 2014. Hubungan Kebiasaan Olahraga dengan Kejadian Dismenore pada Siswi di SMP N 2 Demak Tahun 2014. Program Studi Diploma IV Kebidanan STIKES Ngudi Waluyo Ungaran. Available from : http://perpusnwu.web.id/karyailmiah/documents/3704.pdf. Accessed : 6 Desember 2017

[12] Andriani D, A G, Silakarma D. \& Griadhi A. 2014. Hubungan Antara Kebugaran Fisik Dengan Dismenore Primer Pada Remaja Putri Di SMA Negeri 1 Denpasar Tahun 2014. Majalah Ilmiah Fisioterapi Indonesia, 3. Available from: https://ojs.unud.ac.id/index.php/mifi/article/view/13120. Accessed : 7 Desember 2017

[13] Permana R. 2016. Penguasaan Rangkaian Tes Kebugaran Jasmani Indonesia (TKJI) Melalui Diskusi dan Simulasi (Kajian Pustaka Pemahaman Teori dan Praktek TKJI Terhadap Mahasiswa PGSD UMTAS). Refleksi Edukatika, 6. Available from : https://jurnal.umk.ac.id/index.php/RE/article/viewFile/603/617. Accessed : 12 Desember 2018

[14] Committee on Physical Activity and Physical Education in the School Environment; Food and Nutrition Board; Institute of Medicine; Kohl HW III, Cook HD, editors. Educating the Student Body: Taking Physical Activity and Physical Education to School. Washington (DC): National Academies Press (US); 2013 Oct 30. 4, Physical Activity, Fitness, and Physical Education: Effects on Academic Performance. Available from: https://www.ncbi.nlm.nih.gov/books/NBK201501/

[15] Sulistiono A A. 2014. Kebugaran Jasmani Siswa Pendidikan Dasar dan Menengah di Jawa Barat. Jurnal Pendidikan dan Kebudayaan, 20, 223- 233.

[16] Hastuti T. A. 2008. Kontribusi Ekstrakurikuler Bolabasket Terhadap Pembibitan Atlet dan Peningkatan Kesegaran Jasmani. Jurnal Pendidikan Jasmani Indonesia, 5. Available from : https://journal.uny.ac.id/index.php/jpji/article/viewFile/454/pdf. Accessed : 12 Desember 2018

[17] Kasrin R. \& Putri R B. 2013. Hubungan Kebiasaan Olahraga dengan Dismenore pada Siswi SLTPN 7 Bukittinggi Tahun 2012. Jurnal Kesehatan Volume 4 No. 1, Januari 2013, 4.

[18] Anwar M, Baziad A, Prabowo R P. 2011. Ilmu Kandungan, Edisi ketiga. Jakarta : PT Bina

[19] Pustaka Sarwono Prawiroharjo 